\title{
Communication/Comunicação
}

\section{Cocirculation of two dengue virus serotypes in individual and pooled samples of Aedes aegypti and Aedes albopictus larvae}

\author{
Cocirculação de dois sorotipos do vírus dengue em amostras individuais e pools de larvas de \\ Aedes aegypti e Aedes albopictus
}

\section{José Eduardo Marques Pessanha ${ }^{1,2}$, Waleska Teixeira Caiaffa ${ }^{2,3}$, Alzira Batista Cecilio ${ }^{4}$, Felipe Campos de Melo Iani $^{4}$, Simone Costa Araujo ${ }^{1}$, José Carlos Nascimento ${ }^{1}$, Erna Geessien Kroon ${ }^{5}$, Fernando Augusto Proietti ${ }^{2}$ and Jorge Rodriguez Arias ${ }^{6}$}

\begin{abstract}
Introduction: To detect dengue virus, eggs of Aedes $s p$ were collected in the city of Belo Horizonte, Brazil, in 2007. Methods: Egg samples were subsequently hatched and the larvae were tested for the presence of dengue virus RNA by RT-PCR. Results: Among the Aedes aegypti larvae samples, $163(37.4 \%)$ out of 435 were positive, including 32 (10.9\%) of 293 individual larvae samples concomitantly positive for two serotypes. Conclusions: Virological surveillance detecting coinfected vectors in the field could represent an important strategy for understanding the numerous factors involved in the transmission and clinical presentation of dengue.
\end{abstract}

Keywords: Dengue. Virus. Serotypes. Vectors.

\section{RESUMO}

Introdução: Para a detecção do vírus da dengue, ovos de Aedes sp foram coletados em Belo Horizonte, Brasil, em 2007. Métodos: Amostras de ovos eclodiram e suas larvas foram testadas para a presença de RNA do vírus dengue por RT-PCR. Resultados: Das amostras de larvas de Aedes aegypti, $163(37,4 \%)$ de 435 foram positivas, incluindo 32 (10,9\%) das 293 amostras individuais que foram concomitantemente positivas para dois sorotipos. Conclusões: A vigilância virológica de vetores no campo poderia representar uma estratégia importante para a compreensão dos diversos fatores envolvidos na transmissão e apresentação clínica da dengue.

Palavras-chaves: Dengue. Vírus. Sorotipos. Vetores.

Dengue is an acute viral disease transmitted primarily by Aedes aegypti and the infectious agent is one of four serotypes of the dengue virus (DENV): DENV-1, DENV-2, DENV-3 or DENV-4. The incidence of dengue fever and dengue hemorrhagic fever (DHF) has increased in tropical regions of the Americas ${ }^{1}$. In Brazil, over the past 22 years, the geographic expansion of the vector has enhanced the cocirculation of serotypes DENV-1, DENV-2 and DENV-3 in 25 of the 27 Brazilian states ${ }^{2}$.

1. Municipal Health Secretariat of Belo Horizonte, Belo Horizonte, MG, Brazil. 2. Urban Health Observatory, Universidade Federal de Minas Gerais, Belo Horizonte, MG, Brazil. 3. Research Group in Epidemiology, Department of Social and Preventive Medicine, Universidade Federal de Minas Gerais, Belo Horizonte, MG, Brazil. 4. Molecular Virology and Bioproducts Laboratory, Research and Development Department, Fundação Ezequiel Dias, Belo Horizonte, MG, Brazil. 5. Virus Laboratory, Department of Microbiology, Institute of Biological Sciences, Universidade Federal de Minas Gerais, Belo Horizonte, MG, Brazil. 6. Disease Carrying Insects Program, Fairfax County, Health Department, Fairfax, Virginia, USA.

Address to: Dr. José Eduardo Marques Pessanha. SMS/BH. Av. Afonso Pena 2336 $4^{\circ}$ andar, 30130-007 Belo Horizonte, MG.

Phone: 5531 3277-8214

e-mail: edumpessanha@hotmail.com

Received in $02 / 12 / 2009$

Accepted in 30/09/2010
In the fall of 1996, DENV-1 was introduced to the City of Belo Horizonte, the capital of the State of Minas Gerais, resulting in a localized outbreak. In 1997, other outbreak occurred in the city during the summer and fall.

After a silent period during the winter and spring of 1997, a new and large epidemic cycle began in Belo Horizonte and continued throughout the summer and fall of 1998, during which the mean incidence rate was 381 per 10,000 inhabitants $^{3-5}$. At that time, DENV-2 was isolated cocirculating with DENV-1.

A seroepidemiological survey was conducted by our group using a serum-neutralization assay. A seroprevalence of $23 \%$ was determined, with one in four of these cases demonstrating concurrent seropositivity for DENV-1 and DENV-2 ${ }^{5}$. Other studies during the same period, using reverse transcription-polymerase chain reaction (RT-PCR) in pooled larvae collected in the nine administrative districts of the city, also detected samples positive for DENV-1 and DENV- ${ }^{6}$.

In 2002, DENV-3 was isolated from human serum for the first time in the city. Since then, cocirculation of DENV-1, DENV-2 and DENV-3 has occurred in the State of Minas Gerais and this cocirculation has been documented molecularly and by isolation, demonstrating the genotypic variation of DENV in the state ${ }^{7}$.

During epidemiological weeks 13 and 14 of 2007 (March $25^{\text {th }}$ to April $7^{\text {th }}$ ), eggs were collected from positive ovitraps (of 486 placed) in three administrative districts of Belo Horizonte (Central-South, East, and Venda Nova). The larvae of $A$. aegypti and A. albopictus that hatched from these eggs were reared to $4^{\text {th }}$ instar, identified at a species level and examined for DENV.

In order to determine whether more than one serotype could be present in a single larva, the hatched larvae were distributed into individual and multiple larval pools. The A. aegypti pools had an average of eight larvae (range 2 to 10 ) and the two Aedes albopictus pools had 3 and 6 larvae each. The samples were then sent to the Molecular Virology and Bioproducts Laboratory of the Ezequiel Dias Foundation for RT-PCR analysis. The silica method was used to extract RNA from the larva samples ${ }^{8}$. Approximately $1 \mu \mathrm{g}$ to $5 \mu \mathrm{g}$ of extracted RNA was added to $50 \mathrm{pmol}$ of oligonucleotide antisense primers and $200 \mathrm{U}$ of reverse transcriptase (SuperScript II RT - Gibco/Life Technologies) to generate the cDNA. The oligonucleotide primers used for the detection of DENV have been previously described ${ }^{9}$. As a positive control for the assays, cDNA prepared from RNA extracted from the supernatant taken from the 
cellular culture of C6/36 cells infected with standard specimens of DENV-1, DENV-2 and DENV-3 was used. For negative controls, sterile water was used. The amplification cycles were: one cycle at $95^{\circ} \mathrm{C}(3 \mathrm{~min}), 30 \mathrm{cycles}$ at $95^{\circ} \mathrm{C}(/ 15 \mathrm{~s}$ each $)$, one cycle at $55^{\circ} \mathrm{C}(15 \mathrm{~s})$ and finally one cycle at $72^{\circ} \mathrm{C}(30 \mathrm{~s})$.

A total of 13,436 Aedes sp eggs were detected in 247 (50.8\%) of the 486 ovitraps, with an egg density Index $(\mathrm{EDI})^{10}$ of 54.4 . Of the $3,604(26.8 \%)$ eggs that hatched, 3,587 (99.5\%) were A. aegypti and 17 (0.5\%) were A. albopictus. Due to logistical constraints, a sample of 1,400 (39\%) of the A. aegypti larvae were tested with RT-PCR. These larvae were selected using a stratified sampling process to assure proportional representation from all three administrative districts (Table 1). All 17 A. albopictus larvae were tested.

The 1,417 larvae that were tested were divided into 445 samples, 435 Aedes aegypti (293 individual samples and 142 pools) and ten $A$. albopictus (eight individual samples and two pools). Among the $A$. aegypti samples, 163 (37.4\%, 95\%CI: 32.9\%-42.2\%) were positive for DENV. Among the A. albopictus individual and pool samples, five (50\%, 95\%CI: 20.1-79.9) were positive (Table 2).

Among the A. aegypti larvae, DENV-2 was most frequently detected $(\mathrm{n}=93,21.4 \%)$. DENV-1 and DENV-2 were detected concomitantly in 29 samples (6.7\%): 22 in individual larvae and seven in pooled specimens. DENV-2 and DENV-3 coinfection was detected in 14 (3.2\%) samples, nine of which were individual samples. Among the A. albopictus larvae, DENV-2 was the most frequently isolated serotype $(n=2,4 \%)$, with one sample coinfected with DENV-2 and DENV-3. DENV-1 and DENV-3 coinfections were not detected in either species of mosquito.

Infection rates (IR) for the various dengue viruses were determined using an Excel add-in ${ }^{11}$. The infection rates of the different dengue viruses, expressed as maximum likelihood estimates (MLE) are presented in Table 3. The overall IR for dengue virus in the
TABLE 1 - Frequency distribution of placed ovitraps, ovitraps with eggs, and hatched eggs for two mosquito species, Belo Horizonte, 2007.

\begin{tabular}{lc}
\hline Ovitraps placed & 486 \\
\hline Ovitraps with eggs & 247 \\
$\mathrm{n}$ & 50.8 \\
$\%$ & 13,436 \\
\hline Total eggs & 54.4 \\
egg density index (EDI) & $3,604(26.8 \%)$ \\
\hline Hatched eggs & $3,587(99.5 \%)$ \\
Aedes aegypti & $17(0.5 \%)$ \\
Aedes albopictus & $1,400(39 \%)$ \\
\hline Aedes aegypti larvae tested with RT-PCR & 293 \\
individual samples & 142 \\
pooled samples (pool average $=8 ; \mathrm{n}=2$ to 10$)$ & 435 \\
total samples & $17(100 \%)$ \\
\hline Aedes albopictus larvae RT-PCR tested & 8 \\
individual samples & 2 \\
pooled samples (n = 3 \& 6) & 10 \\
total samples & \\
\hline RT-PCR reverse transciption-polymerase chin reaction. & \\
\hline
\end{tabular}

RT-PCR: reverse transcription-polymerase chain reaction.

A. aegypti larvae was $138.6 / 1,000$ or $13.9 \%$ and DENV-2 was the predominant serotype with an overall IR of $11.1 \%$. The IR of DENV-2 was $7.3 \%$ when was detected alone in pools, $2.1 \%$ when detected in combination with DENV-1 and $1.1 \%$ when detected in combination with DENV-3. The second most frequently detected was DENV-1 with an overall IR of $3.3 \%$. The IR of DENV-1 was $1.2 \%$ when was detected alone in pools and $2.1 \%$ when detected in combination with DENV-2. The least frequently detected was DENV-3 with an overall IR of $1.8 \%$. The IR of DENV-3 was $0.8 \%$ when detected alone in pools and $1 \%$ when detected in combination with DENV-2. No DENV1 and DENV-3 coinfections were detected.

TABLE 2 - RT-PCR test results among larvae of dengue vectors, according to dengue virus serotype, for two mosquito species, Belo Horizonte, 2007.

\begin{tabular}{|c|c|c|c|c|c|c|c|c|c|c|c|}
\hline \multirow{3}{*}{$\frac{\text { Samples }}{\text { Aedes Aegypti }}$} & \multirow{3}{*}{$\begin{array}{c}\text { DENV } \\
\text { (all serotypes) }\end{array}$} & \multirow{3}{*}{ DENV-1 } & \multirow{3}{*}{ DENV-2 } & \multirow{3}{*}{ DENV-3 } & \multirow{3}{*}{$\begin{array}{l}\text { DENV-1 and } \\
\text { DENV-2 }\end{array}$} & \multirow{3}{*}{$\begin{array}{c}\text { DENV-2 and } \\
\text { DENV-3 }\end{array}$} & \multirow{3}{*}{ NEG } & \multirow{2}{*}{\multicolumn{2}{|c|}{$\begin{array}{c}\text { Positive } \\
\%\end{array}$}} & \multirow{2}{*}{\multicolumn{2}{|c|}{$95 \% \mathrm{CI}$}} \\
\hline & & & & & & & & & & & \\
\hline & & & & & & & & & & & \\
\hline individual & 110 & 10 & 60 & 8 & 22 & 10 & 183 & 293 & 37.5 & 32.0 & 43.4 \\
\hline pool & 53 & 6 & 33 & 3 & 7 & 4 & 89 & 142 & 37.3 & 29.5 & 45.9 \\
\hline total n (\%) & $163(37.4)$ & $16(3.7)$ & $93(21.4)$ & $11(2.5)$ & $29(6.7)$ & $14(3.2)$ & $272(62.6)$ & $435(100.0)$ & 37.4 & 32.9 & 42.2 \\
\hline \multicolumn{12}{|c|}{ Aedes Albopictus } \\
\hline pool & 1 & --- & 1 & --- & ---- & --- & 1 & 2 & 50.0 & 2.7 & 97.3 \\
\hline total $\mathrm{n}(\%)$ & $5(50.0)$ & --- & $4(40.0)$ & --- & --- & $1(10.0)$ & $5(50.0)$ & $10(100.0)$ & 50.0 & 20.1 & 79.9 \\
\hline
\end{tabular}

---: negative samples, DENV: dengue virus.

TABLE 3 - Infection rate per 1,000 (expressed as maximum likelihood estimation with $95 \% \mathrm{CI}$ ) of the various dengue virus serotypes in Aedes aegypti, Belo Horizonte, 2007.

\begin{tabular}{lrrrrrrrcc}
\hline & $\begin{array}{c}\text { Infection } \\
\text { Rate }\end{array}$ & $\begin{array}{c}\text { Lower } \\
\text { Limit* }\end{array}$ & $\begin{array}{c}\text { Upper } \\
\text { Limit* }\end{array}$ & Scale & Point Est Method & CI Method & $\begin{array}{c}\text { Num } \\
\text { Pools }\end{array}$ & $\begin{array}{c}\text { Num } \\
\text { Pos } \\
\text { Pools }\end{array}$ & $\begin{array}{c}\text { Num } \\
\text { Individuals }\end{array}$ \\
\hline DENV-1 only & 11.61 & 6.94 & 18.31 & 1,000 & Bias Corrected MLE & Corrected Score & 435 & 16 & 1,400 \\
DENV-2 only & 72.90 & 60.40 & 87.30 & 1,000 & Bias Corrected MLE & Corrected Score & 435 & 93 & 1,400 \\
DENV-3 only & 7.88 & 4.19 & 13.57 & 1,000 & Bias Corrected MLE & Corrected Score & 435 & 11 & 1,400 \\
DENV-1 \& DENV -2 & 20.96 & 14.51 & 29.34 & 1,000 & Bias Corrected MLE & Corrected Score & 435 & 29 & 1,400 \\
DENV-2 \& DENV -3 & 10.09 & 5.80 & 16.39 & 1,000 & Bias Corrected MLE & Corrected Score & 435 & 14 & 1,400 \\
All DENV -1 & 33.18 & 24.88 & 43.39 & 1,000 & Bias Corrected MLE & Corrected Score & 435 & 45 & 1,400 \\
All DENV -2 & 11.00 & 95.92 & 127.96 & 1,000 & Bias Corrected MLE & Corrected Score & 435 & 136 & 1,400 \\
All DENV -3 & 18.12 & 12.14 & 26.07 & 1,000 & Bias Corrected MLE & Corrected Score & 435 & 25 & 1,400 \\
All DENV (1, 2 \& 3) & 138.60 & 121.84 & 157.29 & 1,000 & Bias Corrected MLE & Corrected Score & 435 & 163 & 1,400 \\
\hline MLE: maximum likelihood estimates, DENV: dengue virus, ${ }^{*} 95 \%$. & & & &
\end{tabular}


In 1996 and 1997, only DENV-1 was detected in human sera submitted to the Belo Horizonte City Health Department Epidemiological Surveillance Service. Beginning in 1998, DENV-2 was also isolated ${ }^{3}$. Since 2002, DENV-3 has been predominantly isolated. It is interesting to note that in the present study, DENV-2 was the most frequently detected serotype.

Sabin demonstrated the occurrence of transovarial transmission of DENV-2 by A. aegypti in nature by the isolation of dengue virus from naturally infected mosquito larvae showing a minimum infection rate of 1:2,067 for DENV-2 ${ }^{12}$. Natural transovarial transmission of DENV-4 by A. aegypti was demonstrated from adult mosquitoes reared in the laboratory from eggs collected in Trinidad, with a minimum infection rate of $1: 1,855^{13}$. The results of laboratory experiments described above with $A$. aegypti showed a very inefficient minimum infection rate. Cecilio et al determined an infection rate for DENV-2 of 1:35.45, indicating that transovarial transmission of DENV by A. aegypti could provide a mechanism for the maintenance of DENV when continuous mosquito breeding is interrupted ${ }^{6}$. Transovarial transmission was confirmed by the detection of DENV-2 in male mosquitoes hatched from eggs which were collected in nature and reared in controlled conditions.

The detection of coinfection by two serotypes in a single larva of the vector means that the new generations of mosquitoes could be coinfected by transovarial transmission. To our knowledge, this is the first report in the Brazilian literature of double infection by different serotypes of the dengue virus detected in individual larvae.

Human cases of concurrent infections by two serotypes have been reported in Brazil: in the City of Cuiabá, State of Mato Grosso (DENV-1 and DENV-2) ${ }^{14}$ and more recently in the City of Fortaleza, State of Ceará (DENV-2 and DENV-3) ${ }^{15}$.

The true epidemiological significance of the transmission of two or more serotypes by vectors that acquired the virus by transovarial transmission has yet to be established. The present results raise several questions related to the infectivity of these coinfected vectors, their significance in transmission during silent periods (interepidemic) and the relation between simultaneous infection by two serotypes and the clinical severity of cases. Virological and entomological surveillance detecting coinfected vectors in the field could represent an important strategy for increasing current understanding of the various factors involved in the transmission and clinical presentation of dengue and improving the monitoring of the dynamic of its occurrence.

\section{ACKNOWLEDGMENTS}

The authors would like to thank the Zoonosis Control team of the City of Belo Horizonte Health Department.

\section{CONFLICT OF INTEREST}

The authors declare that there are no conflicts of interest.

\section{FINANCIAL SUPPORT}

This study was partially funded by the Pan-American Health Organization and Conselho Nacional de Desenvolvimento Científico e Tecnológico (CNPq). The authors EGK, FAP and WTC are recipients of research fellowships from the $\mathrm{CNPq}$.

\section{REFERENCES}

1. Gubler DJ, Clark GG. Community involvement in the control of Ae. aegypti. Acta Trop 1996; 61:169-179.

2. Secretaria de Vigilância em Saúde. Saúde Brasil 2005 - Uma Análise da Situação de Saúde, Análise da Situação da Dengue e do Programa de Controle da Dengue no Brasil. Brasília: DF. Ministério da Saúde; 2006.

3. Corrêa PRL, França E, Bogutchi TF. Aedes aegypti infestation and occurrence of dengue in the city of Belo Horizonte, Brazil. Rev Saude Publica 2005; 39:33-40.

4. Almeida MC, Caiaffa WT, Assunção RM, Proietti FA. Dinâmica intra-urbana das epidemias de Dengue em Belo Horizonte, MG, 1996-2002. Cad Saude Publica 2008; 24:2385-2395.

5. Cunha MCM, Caiaffa WT, Olivieira CL, Pessanha JEM, Lima JA, Proietti FA Fatores Associados a Infecção do Dengue no Município de Belo Horizonte, Capital do Estado de Minas Gerais, Brasil: Características Individuais e Diferenças Intra-Urbanas. Epidemiol Serv Saude 2008; 17:217-230.

6. Cecílio AB, Resende MC, Jorge FC, Resende SM, Brito MG, Kroon EG Transovarial transmission of dengue virus 1 and 2 as showed by detection in Ae. aegypti larvae. Vírus Rev Res 2004; 9:57-60

7. Figueiredo LB, Cecílio AB, Ferreira GP, Drumond BP, de Oliveira JG, Bonjardim CA, et al. Dengue virus 3 genotype 1 associated with dengue fever and dengue hemorrhagic fever, Brazil. Emerg Infect Dis 2008; 14:314-316.

8. Boom S, Salimans CJ, Jansen MM, Wertheim-Van CJ, Dillen PM, Van der Noordaa J. Rapid and simple method for purification of nucleic acids. J Clin Microbiol 1990; 28:495-503.

9. Chien LJ, Liao TL, Shu PY, Huang JHH, Gubler DJ, Chang GJJ. Development of real-time reverse transcriptase PCR assays to detect and serotype Dengue viruses. J Clin Microbiol 2006; 44:1295-1304.

10. Gomes AC. Medidas dos níveis de infestação urbana para Aedes (Stemomyia) Aegypti eAedes (Stegomyia) albopictus em Programa de Vigilância Entomológica. In: Informe Epidemiológico do SUS. Brasília: Ministério da Saúde; 1998. p.49-57.

11. Biggerstaff BJ. PooledInfRate, Version 3.0: a Microsoft ${ }^{\circledR}$ Excel ${ }^{\circledR}$ Add-In to compute prevalence estimates from pooled samples [Internet]. 2006. Fort Collins (CO): Centers for Disease Control and Prevention. [cited Oct, 2007]. Available from: http://www.cdc.gov/ncidod/dvbid/westnile/software.htm/.

12. Sabin AB. Research on dengue during World War II. Am J Trop Med Hyg $1952 ; 1: 30-50$

13. Hull B, Tikasingh E, Souza M, Martinez R. Natural transovarial transmission of dengue 4 virus in Aedes aegypti in Trinidad. Am J Trop Med Hyg 1984; 33:1248-1250

14. Rocco IM, Barbosa ML, Kanomata EHN. Simultaneous infection with Dengue 1 and 2 in a Brazilian Patient. Rev Inst Med Trop 1998; 40:151-154.

15. Araújo FCM, Nogueira RMR, Araújo JMG, Ramalho ILC, Sá Roriz MLF Melo MEL, et al. Concurrent infection with dengue virus type-2 and DENV-3 in a patient from Ceará, Brazil. Mem Inst Oswaldo Cruz 2006; 101:925-928. 